\title{
The elemental composition and origin of fine ambient particles in the largest Polish conurbation: first results from the short-term winter campaign
}

\author{
Grzegorz Majewski $^{1}$ - Wioletta Rogula-Kozłowska ${ }^{2}$
}

Received: 19 March 2015 / Accepted: 24 April 2015 /Published online: 10 May 2015

(C) The Author(s) 2015. This article is published with open access at Springerlink.com

\begin{abstract}
Diurnal (24-h) samples of fine particulate matter $\left(\mathrm{PM}_{2.5}\right.$, ambient particles with an aerodynamic diameter not greater than $2.5 \mu \mathrm{m}$ ) and soil samples were collected in an urban area in Warsaw, in winter. The samples were analysed for 24 elements with an Epsilon 5 spectrometer (PANalytical). The results were then arranged and compared with the results of research conducted earlier in Poland and other parts of the world. Afterwards, sources of ambient $\mathrm{PM}_{2.5}$ were identified and the share of each in the concentration of $\mathrm{PM}_{2.5}$ was evaluated by means of enrichment factor (EF) analysis, principal component analysis (PCA) and multi-linear regression analysis (MLRA). The results were interpreted using a detailed analysis of correlations between diurnal concentrations of $\mathrm{PM}_{2.5}, \mathrm{PM}_{2.5}$-elements, and of changes in meteorological conditions. The winter average ambient concentration of $\mathrm{PM}_{2.5}$ in Warsaw, was $10.7 \pm 7.5 \mu \mathrm{g} / \mathrm{m}^{3}$ and was much lower than in the other sites in Poland. In Warsaw, regardless of the concentration of $\mathrm{PM}_{2.5}$, the concentrations of certain $\mathrm{PM}_{2.5}$-bound elements, mainly toxic, were high, e.g. the average ambient concentrations of $\mathrm{PM}_{2.5}$-bound $\mathrm{Se}, \mathrm{As}, \mathrm{Co}, \mathrm{V}, \mathrm{Cd}$ and $\mathrm{Ni}$ were $12.7 \pm 30.5,10.6 \pm 34.4,9.4 \pm 13.7,15.1 \pm 32.7,9.6 \pm 22.2$ and $3.5 \pm 5.0 \mathrm{ng} / \mathrm{m}^{3}$, respectively. The elemental composition and concentrations of $\mathrm{PM}_{2.5}$ appeared to be influenced mainly by the anthropogenic emissions (energy production based on coal
\end{abstract}

Grzegorz Majewski

grzegorz_majewski@sggw.pl

Wioletta Rogula-Kozłowska wioletta@ipis.zabrze.pl

1 Department of Meteorology and Climatology, Warsaw University of Life Sciences - SGGW, 166 Nowoursynowska St., 02-776 Warszawa, Poland

2 Institute of Environmental Engineering, Polish Academy of Sciences, 34 M. Skłodowska Curie St., 41-819 Zabrze, Poland and biomass combustion, whose mean contribution to the concentration of $\mathrm{PM}_{2.5}$ was $18.4 \%$, and energy production based on oil combustion with a contribution of $9.9 \%$ in $\mathrm{PM}_{2.5}$ ). A mixture of soil matter and road dust was also identified in $\mathrm{PM}_{2.5}(8 \%)$. The mean contribution of traffic (exhaust) emissions to the concentration of $\mathrm{PM}_{2.5}$ in an urban area, selected as representative of the Warsaw conurbation, was assessed at $15.4 \%$.

\section{Introduction}

In recent years, particular attention in air-quality research has been paid to the chemical characteristics of particulate matter (PM) and principally to its fine particle fraction $\mathrm{PM}_{2.5}$ (ambient particles with an aerodynamic diameter not greater than $2.5 \mu \mathrm{m}$ ). There are two main reasons for the interest in $\mathrm{PM}_{2.5}$ compositions. One is the adverse health effect that $\mathrm{PM}_{2.5}$ exerts (Englert 2004; Pope and Dockery 2006; Kennedy 2007; Viana et al. 2008a, b; Belis et al. 2013; Cheng et al. 2014; Daher et al. 2014). The other is the possibility of using such knowledge to manage air quality (assessment of PM emission source percentages, elaboration of actions that will limit the PM concentrations in the researched areas).

The elemental analysis of PM partly characterizes the PM chemical composition; it usually suffices for understanding the temporal and spatial relationship between the source and the receptors of PM and for the assessment of the efficiency of emission abatement methods (Chow 1995; Viana et al. 2008a; Sówka et al. 2012; Zhang et al. 2011). It also provides some information on potential PM health and environmental effects (Swaine 2000; Duvall et al. 2008; Wiseman and Zereini 2009; Lettino et al. 2012; Baxter et al. 2013).

Some elements in PM, including all heavy metals, are considered toxic (Costa and Dreher 1997; Swaine 2000). Even 
though concentrations of toxic elements, such us $\mathrm{As}, \mathrm{Cd}, \mathrm{Pb}$, and $\mathrm{Ni}$, in the air do not normally exceed permissible levels, chronic contact with such pollutants contributes to many adverse health effects, as they accumulate in the body tissues (bones, kidneys, brain; Costa and Dreher 1997; Swaine 2000; WHO 2000; EC 2004). Exposure to their salts or oxides can cause acute or chronic poisonings, tumours, diseases of the cardiovascular and nervous systems, and of the kidneys (Lippmann 2008), and some elements can weaken the immune system in humans (Goyer 1986). The adverse effects of lead are well known (Chow 1995). Some elements are not bioavailable in their elemental forms; although recent studies show that $\mathrm{PM}_{2.5}$-bound heavy metals are bioavailable, the majority occur in well water-soluble compounds (Wiseman and Zereini 2009; Na and Cocker 2009; Rogula-Kozłowska et al. 2013a, b).

The influence on health is determined by the concentration of the elements in the air, their chemical form and the PM fraction type to which they are bound. In PM coming from industrialized and highly urbanized regions, in which nonindustrial combustion (municipal and residential sectors) and traffic are also dominant emission sources, large concentrations of toxic heavy metals are observed (including $\mathrm{Cd}, \mathrm{Pb}$ or Cr; Table 1). The elemental composition of natural PM forms in a completely different way, particularly when considering PM from the seaside and desert areas (Viana et al. 2008a; Campos-Ramos et al. 2011; Bozlaker et al. 2013). In such locations, elements bound to the crustal fraction dominate ( $\mathrm{Si}, \mathrm{Al}, \mathrm{Ca}, \mathrm{K}$ and $\mathrm{Fe}$ ). The biggest differences in the levels of the harmful elements in the air are observed in areas that differ in the degree of anthropopressure, such as urban and background areas and in regions characterized by different emission structure types.

The elemental composition of $\mathrm{PM}_{2.5}$ and the identification of their sources have been the subject of numerous studies (Table 1). Nevertheless, such information and details are still unavailable for the area of Eastern Europe (Viana et al. 2008a; Putaud et al. 2010; Calvo et al. 2013; Rogula-Kozłowska et al. 2014). The available works on PM-bound metal mass size distribution confirm the tendency of PM-bound heavy metals to accumulate in the finest PM particles (e.g. Fernandez et al. 2001; Daher et al. 2012; Rogula-Kozłowska et al. 2012, 2013b; Daher et al. 2014).

Studies of the elemental composition of $\mathrm{PM}_{2.5}$ carried out in Poland have hardly gone beyond the south of the country (Table 2). However, in central Poland, where the population density in the Warsaw conurbation reaches 632 people per square kilometre, the emission conditions are completely different than in the south; the traffic structure and intensity are totally different and so is the density of built-up areas and meteorological conditions that affect the atmospheric dispersion of pollutants (Majewski et al. 2011; Badyda et al. 2015).
This paper presents and discusses results of the elemental composition of $\mathrm{PM}_{2.5}$ obtained in winter from the largest Polish conurbation, situated in the central part of the country. In the heating season (winter) in most urban areas, the combustion of various fuels for heating keeps the PM concentrations high (Table 1). In Poland, episodes of smog and extremely high PM concentrations are frequent, occurring most often at the end of the year (December/January). These are due to municipal emissions and specific weather conditions (Pastuszka et al. 2010; Juda-Rezler et al. 2011; Lewandowska and Falkowska 2013; Czarnecka and Nidzgorska-Lencewicz 2014). For the purposes of this study, PM was sampled in winter (November-December of 2013), when all possible emission sources were active. Emissions from traffic, industry and re-suspended dust are present in Warsaw, throughout the whole year, and municipal emissions (fossil fuel and biomass combustion) grow significantly in late autumn and early winter, but in November-December, the smog episodes and very high municipal emissions, capable of overshadowing the contributions of other sources to PM elemental composition and concentrations, almost certainly do not occur (Rogula-Kozłowska et al. 2014; http:// powietrze.gios.gov.pl/gios/). This selection of the sampling period favoured determination of the elemental composition and identification of all possible sources of $\mathrm{PM}_{2.5}$.

\section{Materials and methods}

\subsection{Samples collection and preparation}

The observations were conducted in Warsaw $\left(\lambda \mathrm{E}=21^{\circ} 02^{\prime}\right.$, $\left.\varphi \mathrm{N}=52^{\circ} 09^{\prime}\right)$ at a measurement site located in the district of Ursynów, and selected to satisfy the criteria of being an urban background location, as specified in Directive 2008/50/EC (Fig. 1). The topographical, meteorological conditions and the structure and amount of emissions from PM and gas pollution sources (the share of local emissions - from boiler houses and rooms, stoves, industrial facilities and traffic - in the concentration of particulate matter) at the sampling point are typical of the whole agglomeration (Majewski et al. 2011; Majewski et al. 2014).

From 26 November 2013 to 25 December 2013, 30 diurnal samples of $\mathrm{PM}_{2.5}$ were collected by means of an MVS6D PM sampler (provided by ATMOSERVICE; Poznań, Poland). The sampler is equipped with a sampling head that aspires $\mathrm{PM}_{2.5}$ at a flow of $2.3 \mathrm{~m}^{3} / \mathrm{h}$ (according to EN14907). The $\mathrm{PM}_{2.5}$ was collected using PTFE filters $\left(\mathrm{PM}_{2.5}\right.$ Air Monitoring Membrane, PTFE, $46.2 \mathrm{~mm}$ with support ring, CAT. No. 7592-104; GE Healthcare Bio-Sciences Corp.; Piscataway, NJ, USA). The mass of the $\mathrm{PM}_{2.5}$ was determined by weighing the filters before and after exposure; MYA 5.3Y.F micro balance (RADWAG; Radom, Poland) was used 


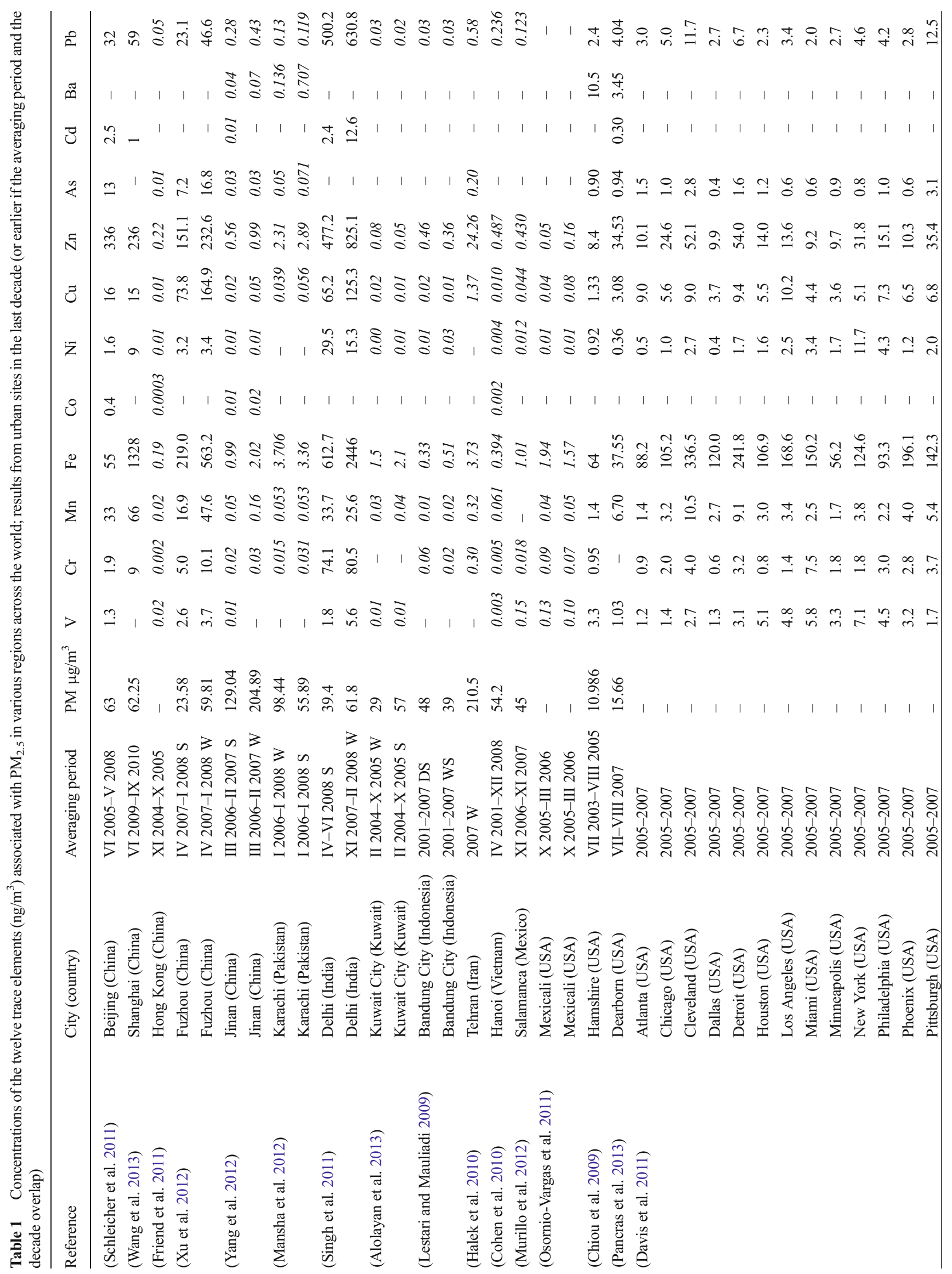




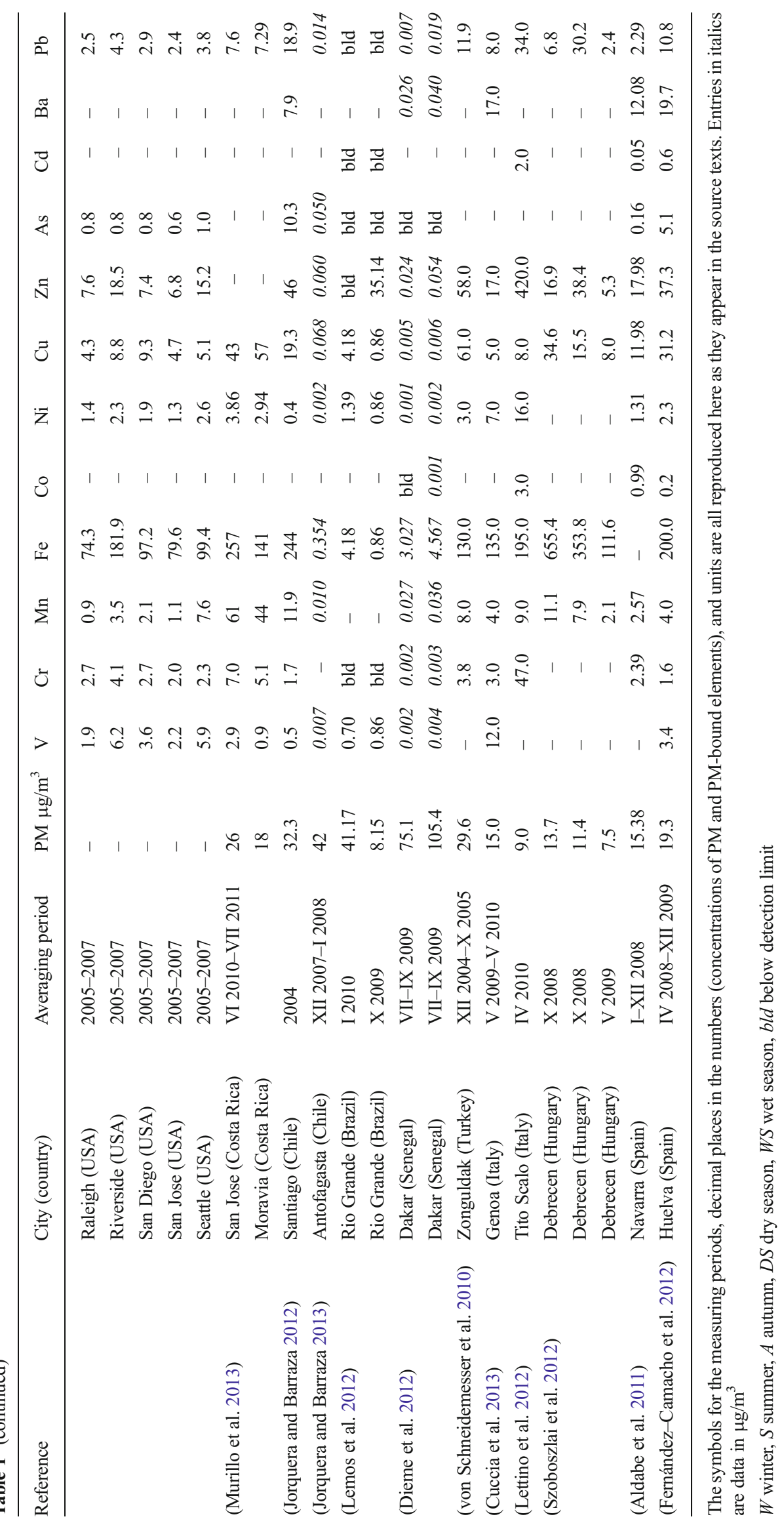




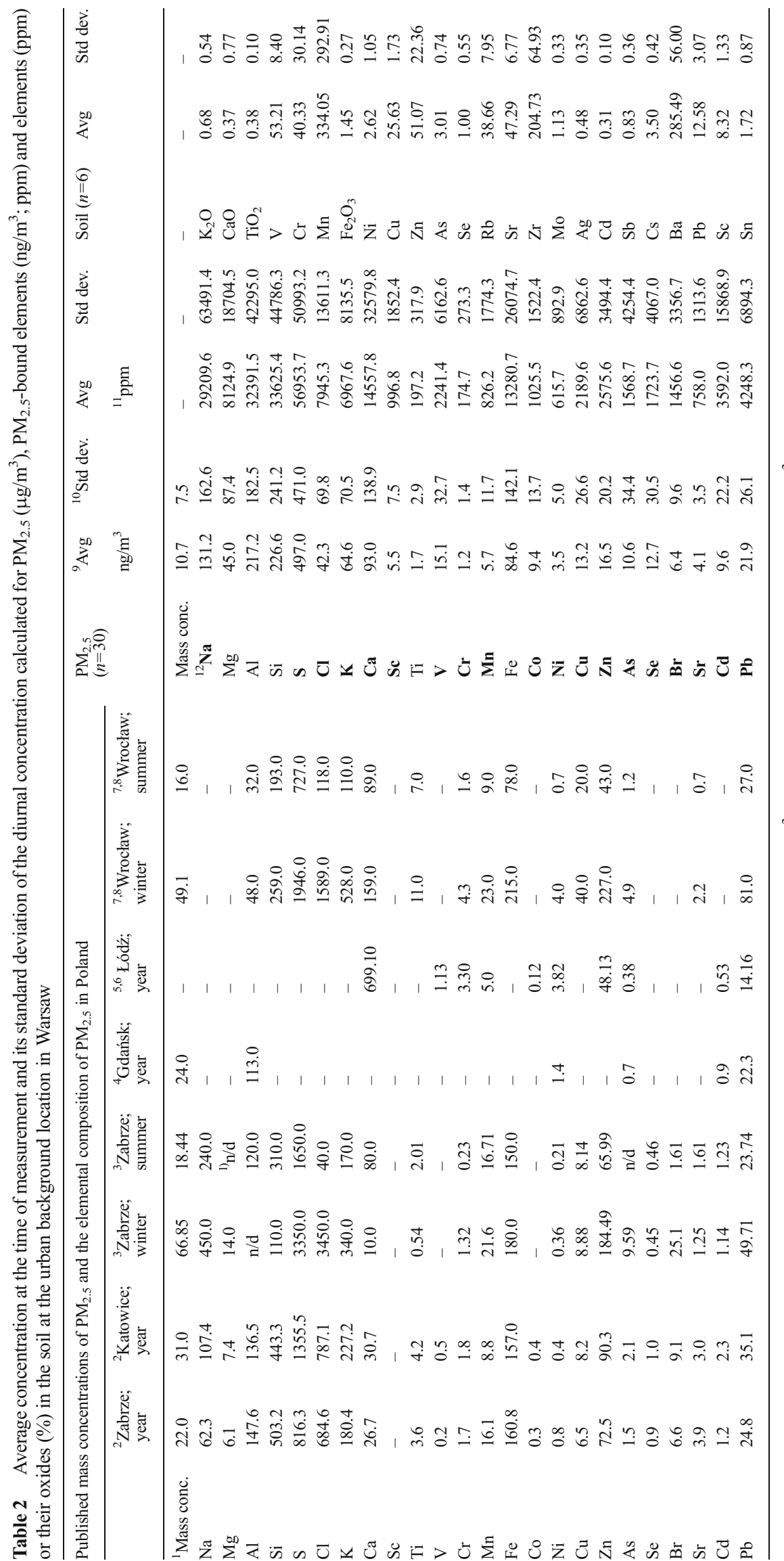

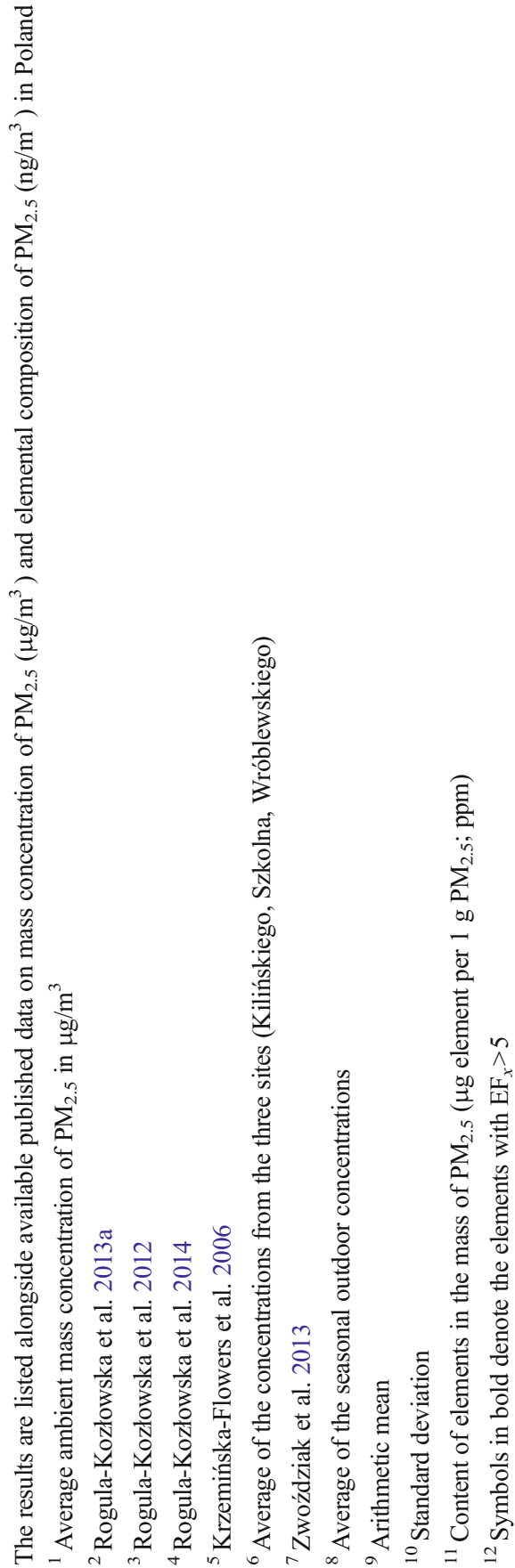



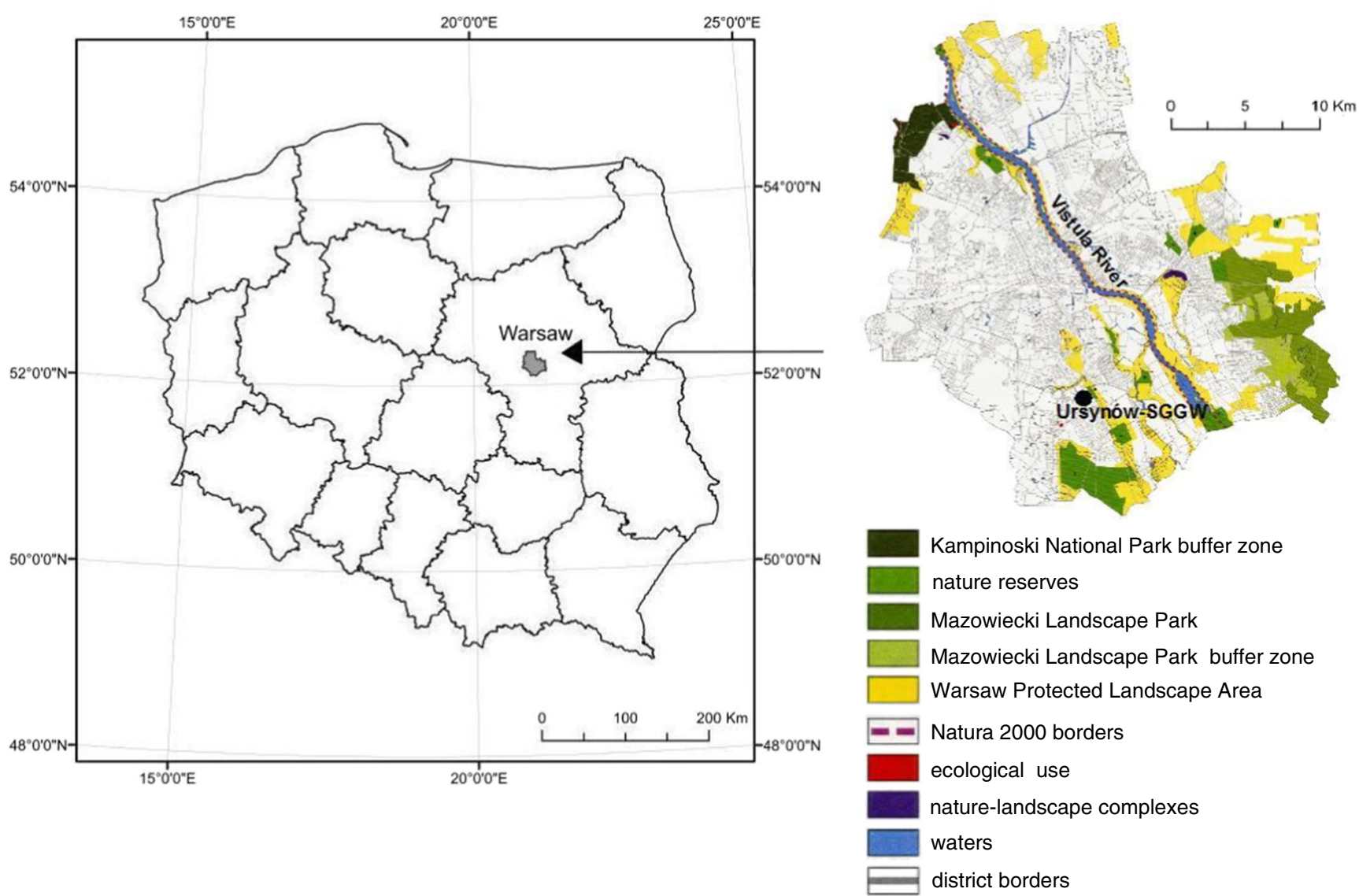

Fig. 1 Location of the sampling point in Warsaw (Poland)

(1- $\mu$ g resolution). Before each weighing, the filters were conditioned for $48 \mathrm{~h}$ in the weighing room (relative air humidity $45 \pm 5 \%$, air temperature $20 \pm 2{ }^{\circ} \mathrm{C}$ ).

In the course of the observations, values of basic meteorological parameters were measured at the Ursynów Meteorological Station of the Warsaw University of Life Sciences (Ursynów-SGGW) according to instructions for the network of state weather stations operated by the Institute of Meteorology and Water Management (IMWM). Hourly results of the measurements were averaged for 24-h intervals from 00:00 to 00:00 h; diurnal samples of $\mathrm{PM}_{2.5}$ were taken at the same times.

The Warsaw location was also used to obtain soil samples (approx. $0.5 \mathrm{~kg}$ each) from six places selected in the area around the PM sampler. Three of these were situated within the prevailing wind direction, at a few to a dozen metres from the sampler, whereas in the other three places, the flow direction of air masses was the opposite. The soil samples were collected at a depth of 10 to $20 \mathrm{~cm}$ using a plastic shovel and cloth bags which were then transported to a laboratory. At the laboratory, the samples were first dried in an electric dryer at $105{ }^{\circ} \mathrm{C}$ and then sieved using a nylon screen with a mesh size of $2 \mathrm{~mm}$ in order to remove leaves, twigs and stones, to obtain a homogeneous material for subsequent analysis. Then, the soil samples were dried again until a constant weight was obtained and then ground for $3 \mathrm{~min}$ in a vibrating corundum bowl mill (Testchem, Radlin, Poland). The ground samples were processed mechanically to form pellets. To this end, a carefully weighed amount of soil was mixed with an appropriate amount of binder (synthetic wax-STW wax batch 64; PANalytical B.V.; Almelo, The Netherlands). The mixture was then pressed for 2 min using a manual hydraulic press $(20 \mathrm{t})$.

\subsection{Chemical analyses}

The diurnal samples of $\mathrm{PM}_{2.5}$ and the soil samples were analysed to find their elemental composition. The elemental composition of $\mathrm{PM}_{2.5}$ was determined by means of energy dispersive X-ray fluorescence (EDXRF). An Epsilon 5 (PANalytical B.V.; Almelo, The Netherlands) calibrated with the use of thin-layer single-element standards (Micromatter; Vancouver, Canada) was used to measure the total concentrations of the elements. To control the performance of the analytical procedure, the NIST SRM2873 samples were measured weekly (the recoveries were between 79 and $124 \%$ of the certified value, except $54 \%$ recovery of Co) and X-ray 
tube and detector drift monthly. The detection limits were from $0.3 \mathrm{ng} / \mathrm{cm}^{2}(\mathrm{~Pb})$ to $14.2 \mathrm{ng} / \mathrm{cm}^{2}(\mathrm{Mg})$.

The same method was used to measure the content of elements in the soil pellets. Calibration lines were prepared using 46 certified reference materials, whereas two other materials (SRM2709, SRM2711; NIST) were used to verify the measurement correctness of the calibration (standard sample recovery ranged from $90 \%$ for $\mathrm{V}$ to $114 \%$ for Ni). Certified standards and reference materials were prepared in the same way as the soil samples collected in the field. During the calibration, an analytical programme was developed to include specific parameters (settings and X-ray tube and detector parameters, and the type of secondary anode for individual excitation conditions) in which the soil samples were analysed.

Results of the analyses of the elemental composition of the $\mathrm{PM}_{2.5}$ and soil were averaged and collected in Table 2.

\subsection{Results analyses}

Enrichment factors (EF) allow for assessment of the anthropogenic effect on the concentrations of the $\mathrm{PM}_{2.5}$-related elements. The enrichment factor $\mathrm{EF}_{x}$ is defined for the element $x$ as:

$\mathrm{EF}_{x}=\frac{\left(C_{x} / C_{\text {ref }}\right)_{\mathrm{PM}}}{\left(C_{x} / C_{\text {ref }}\right)_{\text {soil }}}$

where $C_{x}$ and $C_{\text {ref }}$ designate the concentrations of the element $x$ and the reference element, respectively, and $\left(C_{x} / C_{\text {ref }}\right)_{\mathrm{PM}}$ and $\left(C_{x} / C_{\text {ref }}\right)_{\text {soil }}$ are the proportions of these concentrations in PM and in the soil, respectively. In the paper, the observed concentrations $C_{x}$ are related to the concentration $C_{\mathrm{Ti}}$ of Ti. Ti was the only element among typical soil markers that was identified in the Warsaw soil samples. Consequently, $\mathrm{EF}_{\mathrm{Ti}}=1$.

The soil concentrations of those elements that were not identified in the Warsaw soil samples, but were identified in the samples of $\mathrm{PM}_{2.5}$, were taken from data of the chemical characterization of the Earth's upper continental crust (Wedepohl 1995).

$\mathrm{EF}_{x}$ up to 5 indicates the crustal origin of the element $x$, while higher $\mathrm{EF}_{x}$ suggests a strong anthropogenic effect on the concentrations of $x$. In Table 2, the symbols of the elements $x$ with $\mathrm{EF}_{x}>5$ are given in bold. Out of 24 analysed elements, only $\mathrm{Mg}, \mathrm{Al}, \mathrm{Si}, \mathrm{Ti}$ and $\mathrm{Fe}$ demonstrated a crustal origin.

Further analysis of data consisted in the application and the methodology are described by Thurston and Spengler (Thurston and Spengler 1985). This method combines a factor analysis (FA) to identify the possible sources with a multilinear regression analysis (MLRA) to quantify their contribution to PM levels.

The first step in this stage was the principal component analysis (PCA) to the $24 \times 30$ data matrix of the element concentrations representing the diurnal $\mathrm{PM}_{2.5}$-bound element concentrations. Subsequently, the values of new variablesprincipal components (only principal components with eigenvalues $>1.0$ were considered according to Kaiser criterion)were used in an MLRA. All the computations were performed using Statistica 8.0.

\section{Results and discussion}

The average concentration of $\mathrm{PM}_{2.5}$ in Warsaw, was definitely lower than recorded earlier in other parts of the country (Table 2). It was also lower than the $\mathrm{PM}_{2.5}$ concentrations observed in Asian cities but did not really differ from the concentrations recorded in Europe (Table 1). Apart from the amount of emissions, the parameters that proved to have the greatest influence on the pattern of concentrations in Warsaw, in the measurement period were air temperature, precipitation and wind speed. The values of these parameters were exceptionally favourable at the time in terms of the intensity of exchange of air masses and washing away of atmospheric pollutants. The mean monthly temperature of air in November and December 2013 was approximately $2{ }^{\circ} \mathrm{C}$ higher than its corresponding typical mean values recorded throughout the years. At the time of the measurements, the diurnal temperature of air ranged from -2.1 to $6.6{ }^{\circ} \mathrm{C}$. The wind blew mostly from the WSW and SW, which accounted for 50 and $16 \%$, respectively, of all observed directions. The mean diurnal wind speed ranged from 1.6 to $9.4 \mathrm{~m} / \mathrm{s}$. The precipitation total in the analysed period reached $17.5 \mathrm{~mm}$, and days with a precipitation of at least $0.1 \mathrm{~mm}$ made as much as $37 \%$ of the whole period.

Fluctuations of air temperature, precipitation and wind speed clearly affected the concentrations of $\mathrm{PM}_{2.5}$. The average concentration of $\mathrm{PM}_{2.5}$ calculated for days when the diurnal air temperature fell below $0{ }^{\circ} \mathrm{C}$ was approximately $25 \%$ higher than the value of its average concentration on days with temperatures above $0{ }^{\circ} \mathrm{C}$ (Table 3 ). The average concentration of $\mathrm{PM}_{2.5}$ on days without precipitation was also $25 \%$ higher than when it occurred.

The average concentrations of $\mathrm{PM}_{2.5}$ calculated for days on which the mean diurnal wind speed was lower than $5 \mathrm{~m} / \mathrm{s}$ were over two times higher than the average concentrations on days when the wind speed was equal to or higher than $5 \mathrm{~m} / \mathrm{s}$.

On days when the wind speed was low, the atmospheric pressure was observed to exceed $1005 \mathrm{hPa}$, which-by generating downward movement of air-indirectly contributed to increased $\mathrm{PM}_{2.5}$ concentrations in the air.

Diurnal concentrations of all $\mathrm{PM}_{2.5}$-bound elements were not as clearly correlated with temperature, precipitation or wind speed as in the case of $\mathrm{PM}_{2.5}$ alone. Nevertheless, on days with sub-zero temperatures, the concentrations of certain elements, e.g. $\mathrm{Na}, \mathrm{Al}, \mathrm{Si}, \mathrm{Ca}, \mathrm{Ti}, \mathrm{Mn}, \mathrm{Cu}, \mathrm{Br}$ or $\mathrm{Pb}$, were on 
Table 3 Average concentration of $\mathrm{PM}_{2.5}\left(\mu \mathrm{g} / \mathrm{m}^{3}\right)$ and $\mathrm{PM}_{2.5}$-bound elements $\left(\mathrm{ng} / \mathrm{m}^{3}\right)$ in different averaging periods selected because of prevailing atmospheric conditions during the observations

\begin{tabular}{|c|c|c|c|c|c|c|c|c|c|c|c|c|c|c|}
\hline & \multicolumn{2}{|c|}{${ }^{1}$ Precipitation } & \multicolumn{2}{|c|}{${ }^{2}$ Air temperature } & \multicolumn{2}{|c|}{${ }^{3}$ Wind speed } & \multicolumn{2}{|c|}{${ }^{4}$ Air pressure } & \multicolumn{6}{|c|}{${ }^{5}$ Wind direction } \\
\hline & + & - & $>0$ & $<0$ & $<5$ & $>5$ & $>1005$ & $<1005$ & ESE & $\mathrm{SE}$ & SSW & SW & WNW & WSW \\
\hline $\mathrm{PM}_{2.5}$ & 8.8 & 11.7 & 10.0 & 13.2 & 11.7 & 5.7 & 12.2 & 7.6 & 4 & 8.2 & 17.7 & 11.4 & 7.3 & 11.3 \\
\hline $\mathrm{Na}$ & 111.1 & 142.9 & 112.4 & 206.4 & 131.0 & 132.4 & 154.1 & 85.6 & 344.3 & 64.5 & 87.5 & 88.5 & 106.1 & 169.2 \\
\hline $\mathrm{Mg}$ & 27.6 & 55.1 & 48.0 & 33.0 & 50.4 & 18.0 & 57.6 & 19.8 & 131.2 & 25.5 & 30 & 22.4 & 27.1 & 28.3 \\
\hline $\mathrm{Al}$ & 198.6 & 227.9 & 183.5 & 351.8 & 226.7 & 169.5 & 247.4 & 156.7 & 197.9 & 136.8 & 596.6 & 188.7 & 82.2 & 188.4 \\
\hline $\mathrm{Si}$ & 174.1 & 257.0 & 215.2 & 272.1 & 218.7 & 266.2 & 257.6 & 164.7 & 103.1 & 49.9 & 384.8 & 207.8 & 382 & 231.6 \\
\hline S & 543.1 & 470.3 & 572.5 & 195.1 & 511.6 & 424.1 & 512.9 & 465.1 & 615.1 & 287.9 & 569.1 & 588.7 & 382.7 & 531.9 \\
\hline $\mathrm{Cl}$ & 49.3 & 38.3 & 43.6 & 37.4 & 45.3 & 27.7 & 47.1 & 32.8 & 9 & 10.7 & 9 & 46.5 & 9 & 35.3 \\
\hline K & 68.8 & 62.3 & 72.1 & 34.7 & 74.8 & 14.0 & 78.7 & 36.4 & 47.1 & 57 & 133.9 & 132.7 & 37.6 & 42.8 \\
\hline $\mathrm{Ca}$ & 116.6 & 79.3 & 71.6 & 178.3 & 91.7 & 99.2 & 98.3 & 82.4 & 17.8 & 23.7 & 83 & 160.4 & 27.3 & 107.4 \\
\hline $\mathrm{Sc}$ & 8.3 & 3.9 & 6.3 & 2.5 & 4.3 & 11.6 & 4.3 & 7.9 & 1.6 & 6.1 & 7.3 & 1.9 & 6.8 & 6.8 \\
\hline $\mathrm{Ti}$ & 1.5 & 1.8 & 1.5 & 2.3 & 1.4 & 3.2 & 1.5 & 2.2 & 2.1 & 2.2 & 2.7 & 0.3 & 0.2 & 2.2 \\
\hline V & 3.7 & 21.6 & 18.3 & 2.3 & 16.4 & 8.3 & 13.4 & 18.3 & 102.6 & 42.3 & 3.2 & 21.8 & 0.8 & 6.9 \\
\hline $\mathrm{Cr}$ & 0.8 & 1.5 & 1.3 & 0.9 & 1.4 & 0.5 & 1.6 & 0.6 & 2.3 & 1.2 & 2.2 & 0.6 & 0.2 & 1.4 \\
\hline $\mathrm{Mn}$ & 5.9 & 5.6 & 4.8 & 9.3 & 6.7 & 0.8 & 5.8 & 5.6 & 8.1 & 0.8 & 0.8 & 2.4 & 0.8 & 4.6 \\
\hline $\mathrm{Fe}$ & 81.3 & 86.6 & 98.0 & 31.3 & 94.9 & 33.4 & 102.6 & 48.6 & 194.6 & 94.8 & 105.3 & 32.8 & 1 & 86.3 \\
\hline Co & 7.7 & 10.4 & 10.3 & 5.8 & 10.2 & 5.3 & 9.6 & 9.1 & 2.7 & 5.5 & 0.4 & 8.5 & 6.2 & 9.8 \\
\hline $\mathrm{Ni}$ & 3.0 & 3.9 & 3.8 & 2.4 & 4.0 & 1.1 & 4.3 & 1.9 & 0.4 & 10.3 & 0.4 & 4.8 & 0.4 & 2.9 \\
\hline $\mathrm{Cu}$ & 3.9 & 18.7 & 12.2 & 17.3 & 15.4 & 2.7 & 18.0 & 3.7 & 3.7 & 3.9 & 3.4 & 24.9 & 1.4 & 15.9 \\
\hline $\mathrm{Zn}$ & 12.7 & 18.7 & 18.7 & 7.9 & 18.5 & 6.9 & 16.7 & 16.1 & 33.5 & 28.4 & 22 & 9.7 & 3.3 & 13.1 \\
\hline As & 20.6 & 4.9 & 12.5 & 3.1 & 4.2 & 42.6 & 4.4 & 23.1 & 9.5 & 6 & 6.8 & 2.7 & 0.4 & 15.3 \\
\hline $\mathrm{Se}$ & 22.6 & 7.0 & 13.9 & 8.0 & 6.5 & 43.8 & 7.8 & 22.6 & 12.2 & 1.9 & 1.1 & 3.3 & 0.6 & 19.9 \\
\hline $\mathrm{Br}$ & 7.8 & 5.6 & 6.0 & 8.1 & 4.4 & 16.2 & 5.2 & 8.8 & 3.7 & 2.3 & 1.4 & 3 & 0.2 & 10.5 \\
\hline $\mathrm{Sr}$ & 4.0 & 4.1 & 4.7 & 1.8 & 3.9 & 4.9 & 3.2 & 5.8 & 0.6 & 4.7 & 2.4 & 5 & 2.3 & 4.1 \\
\hline $\mathrm{Cd}$ & 16.0 & 5.8 & 11.3 & 2.6 & 5.9 & 28.0 & 5.2 & 18.2 & 1.6 & 5.9 & 3.6 & 6.3 & 6.2 & 14.4 \\
\hline $\mathrm{Pb}$ & 24.9 & 20.2 & 18.1 & 37.2 & 20.1 & 31.1 & 22.3 & 21.3 & 62.8 & 22.9 & 55.2 & 16.4 & 2.9 & 21.2 \\
\hline
\end{tabular}

${ }^{1}$ Average concentrations determined separately for precipitation days $(+)$ and no precipitation days $(-)$

${ }^{2}$ Average concentrations determined separately for days when mean diurnal air temperature was below $0{ }^{\circ} \mathrm{C}(<0)$ and for days when it was $0{ }^{\circ} \mathrm{C}$ or higher $(>0)$

${ }^{3}$ Average concentrations determined separately for days when mean diurnal wind speed was below $5 \mathrm{~m} / \mathrm{s}(<5)$ and for days when it was $5 \mathrm{~m} / \mathrm{s}$ or higher $(>5)$

${ }^{4}$ Average concentrations determined separately for days when mean diurnal air pressure was below $1005 \mathrm{hPa}(<1005)$ and for days when it was $1005 \mathrm{hPa}$ or higher $(>1005)$

${ }^{5}$ Average concentrations determined separately for days when the frequency of occurrence of each of the selected wind directions (ESE, SE, SSW, SW, WNW, WSW) exceeded $60 \%$ within $24 \mathrm{~h}$

average about $40 \%$ higher than on days with positive temperatures. This correlation should suggest a connection with the source of $\mathrm{PM}_{2.5}$ and $\mathrm{PM}_{2.5}$-bound elements within the analysed area. Such elements as $\mathrm{Na}, \mathrm{Mn}, \mathrm{Ca}, \mathrm{Cu}$ and $\mathrm{Br}$ have an evidently anthropogenic origin in the air of the area $\left(\mathrm{EF}_{x}>\right.$ 5 ; Table 2) and most likely come from the combustion of solid fuels (coal and/or biomass) in household stoves or local house boilers. Some may also come from the combustion of liquid fuels in motor vehicle engines (Chow 1995; Sówka et al. 2012; Sanderson et al. 2014; Kumar et al. 2013). These elements were strongly correlated with PC1-PC5 (Table 4).
Other elements that were correlated with the same components included $\mathrm{Cl}, \mathrm{K}, \mathrm{Se}, \mathrm{Fe}, \mathrm{Sc}, \mathrm{As}, \mathrm{Zn}$ and $\mathrm{Cd}$. Depending on the value of correlation between the concentrations of specific elements and subsequent principal components (factor loadings for the elements in PC1-PC5), and based on elemental profiles of $\mathrm{PM}_{2.5}$ from various sources (Table 5), it was established that the primary source of $\mathrm{PM}_{2.5}$ and most of elements it carried was - within the analysed area - the combustion of coal and biomass (Tables 4 and 5). The mean contribution of this source to the concentrations of $\mathrm{PM}_{2.5}$ at the time of the observations was $18.4 \%$. Its 
Table 4 Results from principal components analysis (PCA) and from a multi-linear regression analysis (MLRA) performed for $\mathrm{PM}_{2.5}$ and $\mathrm{PM}_{2.5}$ bound element concentrations

\begin{tabular}{|c|c|c|c|}
\hline Component & Element factor loading & Source $/ \%$ variance & $\begin{array}{l}\text { Average source contributions }(\%) \text { to } \mathrm{PM}_{2.5} \\
\text { concentrations in sampling period (results } \\
\text { from MLRA)* }\end{array}$ \\
\hline PC1 & $\begin{array}{l}\mathrm{Sc}_{-0.79}, \mathrm{Se}_{-0.77}, \mathrm{As}_{-0.77}, \mathrm{Br}_{-0.73}, \mathrm{Cl}_{0.46}, \mathrm{Al}_{0.44}, \mathrm{Mn}_{0.40}, \\
\quad \mathrm{Mg}_{0.37}, \mathrm{Si}_{0.36}, \mathrm{Ca}_{0.32}, \mathrm{Cd}_{-0.31}\end{array}$ & Coal combustion/15.4 & 1.1 Coal and biomass combustion (A)/18.4 \\
\hline PC2 & $\begin{array}{l}\mathrm{Mg}_{0.69}, \mathrm{Zn}_{0.65}, \mathrm{Fe}_{0.63}, \mathrm{Cl}_{0.58}, \mathrm{As}_{0.42}, \mathrm{Se}_{0.41}, \mathrm{Sc}_{0.39} \\
\quad \mathrm{Cu}{ }_{-0.39}, \mathrm{Al}_{0.33}, \mathrm{Mn}_{0.32}\end{array}$ & Coal combustion/11.4 & 4.5 \\
\hline PC3 & $\begin{array}{l}\mathrm{Ca}_{-0.55}, \mathrm{Co}_{-0.53}, \mathrm{Fe}_{0.44}, \mathrm{Mn}_{-0.43}, \mathrm{Sr}_{0.42}, \mathrm{Si}_{-0.41}, \mathrm{Cl}_{-0.40}, \\
\quad \mathrm{Br}_{-0.40}, \mathrm{Cr}_{0.39}, \mathrm{Cu}_{-0.37}, \mathrm{As}_{-0.34}, \mathrm{Zn}_{0.33}, \mathrm{Cd}_{0.31}\end{array}$ & $\begin{array}{l}\text { Biomass or/and coal } \\
\text { combustion/9.8 }\end{array}$ & 1.6 \\
\hline PC4 & $\mathrm{Pb}_{0.77}, \mathrm{Na}_{0.57}, \mathrm{Sr}_{-0.51}, \mathrm{Co}_{-0.45}, \mathrm{~K}_{-0.38}$ & $\begin{array}{l}\text { Biomass or/and coal } \\
\text { combustion } / 8.4\end{array}$ & 9.1 \\
\hline PC5 & $\mathrm{K}_{-0.67}, \mathrm{~S}_{-0.59}, \mathrm{Cu}_{-0.40}, \mathrm{Cl}_{0.37}, \mathrm{Cd}_{0.34}, \mathrm{Ni}_{0.31}, \mathrm{Fe}_{-0.30}$ & Biomass combustion/7.6 & 2.1 \\
\hline PC6 & $\mathrm{V}_{0.54}, \mathrm{Ca}_{-0.45}, \mathrm{Cu}_{0.41}, \mathrm{Cr}_{0.36}, \mathrm{Si}_{0.34}, \mathrm{Co}_{-0.32}, \mathrm{Mg}_{0.31}, \mathrm{Sr}_{-0.31}$ & Oil-fired power plant/6.8 & 3.6 Oil-fired power plant (B)/9.9 \\
\hline PC7 & $\mathrm{Ni}_{0.58}, \mathrm{Mn}^{-}{ }_{0.46}, \mathrm{Si}_{0.43}, \mathrm{Ti}_{-0.41}, \mathrm{Co}_{0.32}, \mathrm{Na}_{0.30}, \mathrm{~V}_{-0.30}$ & Oil-fired power plant $/ 6.3$ & 6.3 \\
\hline PC8 & $\mathrm{Cr}_{0.62}, \mathrm{Sr}_{-0.38}, \mathrm{~S}_{0.37}, \mathrm{Na}_{-0.35}, \mathrm{~V}_{-0.31}$ & Motor vehicles/5.7 & 15.7 Motor vehicles $(\mathrm{C}) / 15.7$ \\
\hline PC9 & $\mathrm{Ti}_{-0.60}, \mathrm{Ni}_{-0.44}, \mathrm{Al}_{0.42}, \mathrm{Cd}_{0.38}$ & Soil and road dust $/ 5.2$ & 2.5 Soil and road dust (D)/8.0 \\
\hline $\mathrm{PC} 10$ & $\mathrm{Ti}_{-0.43}, \mathrm{Si}_{-0.38}, \mathrm{Ni}_{0.33}, \mathrm{Mn}_{0.31}$ & Soil and road dust $/ 4.6$ & 5.5 \\
\hline Total variance & $81.3 \%$ & & $52.0 \%$ \\
\hline
\end{tabular}

Elements with factor loadings $<0.30$ are not included. Elements presented in descending order of their factor loads, with factor loadings indicated as subscript

*The sets of measured $\mathrm{PM}_{2.5}$ diurnal concentrations and the concentrations computed for each day from MLRA-determined contributions were substantially correlated $\left(R^{2}=0.54\right)$

diurnal contribution to the concentrations of $\mathrm{PM}_{2.5}$ ranged from 15.3 to $20.9 \%$ (Fig. 2) and was negatively correlated with air temperature $\left(R^{2}=-0.22\right)$.

It was difficult to clearly assign one of the two identified sources (coal or biomass combustion) to the principal components PC1-PC5. In the case of PC3 and PC4, there were no grounds to make a final choice. The decision to connect PC1 and PC2 with the combustion of coal was based on high correlations with $\mathrm{Se}, \mathrm{As}$ and $\mathrm{Br}$ and an analysis of the connection between diurnal concentrations of $\mathrm{Se}, \mathrm{As}$ and $\mathrm{Br}$ with the wind speed and direction. $\mathrm{PM}_{2.5}$-bound $\mathrm{Se}, \mathrm{As}$ and $\mathrm{Br}$ originate from coal combustion mainly at large power-generation facilities (power plants and combined heat and power plants (Czarnecka and Nidzgorska-Lencewicz 2014; Kumar et al. 2013; Juda-Rezler and Kowalczyk 2013). The average concentrations of these elements were definitely higher in the periods when the air temperature dropped below zero than in above-zero conditions (Table 3). At wind speeds exceeding $5 \mathrm{~m} / \mathrm{s}$, the concentrations of $\mathrm{Se}$, As and $\mathrm{Br}$ were - on average $-400 \%$ higher than on days when the wind speeds were
Fig. 2 Diurnal contributions (\%) of identified sources of $\mathrm{PM}_{2.5}$ $(A$ - coal and biomass combustion, $B$ - oil-fired power plant, $C$-motor vehicles, $D$ - soil and road dust) to the concentrations of $\mathrm{PM}_{2.5}$ in Warsaw in winter against the diurnal air temperature (Temp) and precipitation (Prec)

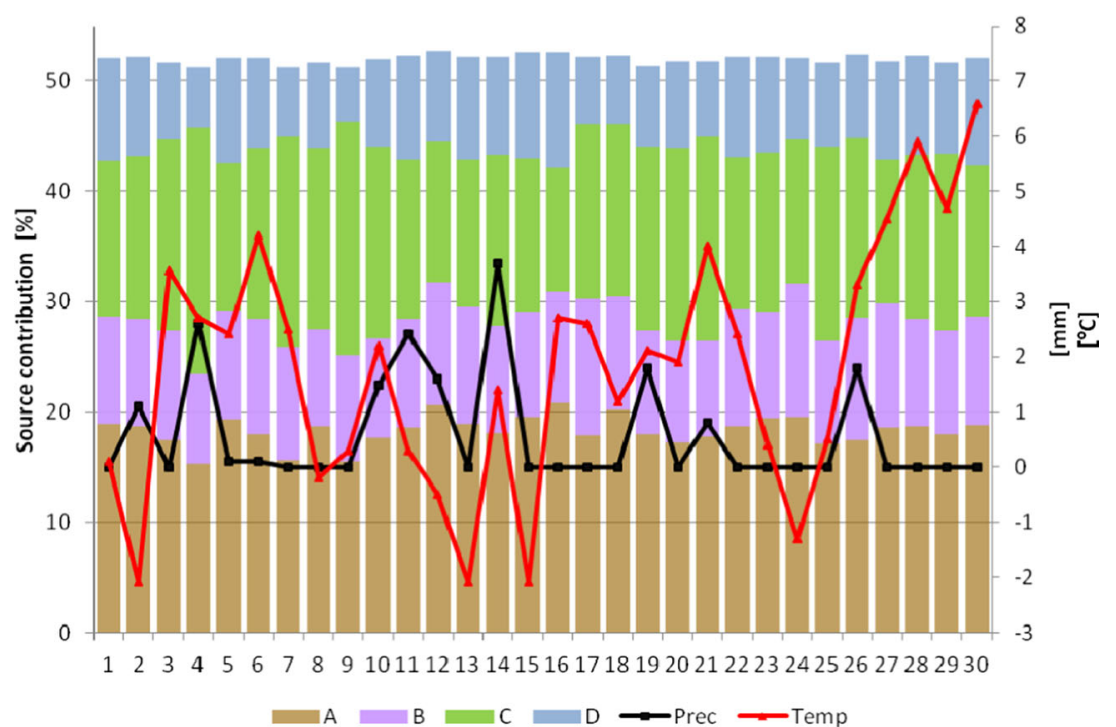


lower than $5 \mathrm{~m} / \mathrm{s}$. Therefore, it is quite possible that at higher wind speeds, $\mathrm{PM}_{2.5}$-bound $\mathrm{Se}, \mathrm{As}$ and $\mathrm{Br}$ came from areas where coal-fired power plants and combined heat and power (CHP) plants are situated. It is understandable that facilities like these, and CHP plants in particular, produce larger amounts of pollution on colder days when the demand for heat and power increases. On days when the concentrations of Se, As and $\mathrm{Br}$ were high - much higher than average - the air was predominantly coming from the WSW (Table 3). This is the direction of large coal-fired boiler houses, a coal-fired power plant (burning coal with biomass) and - further to the southSilesia, an area heavily polluted with $\mathrm{PM}_{2.5}$, the source of which is mainly coal combustion in winter (RogulaKozłowska et al. 2012, 2013 b; 2014).

High correlation values of $\mathrm{K}, \mathrm{S}$ and $\mathrm{Cl}$ with PC5 imply a share of biomass combustion in the concentrations of $\mathrm{PM}_{2.5}$ (the contribution of this source to the concentrations of $\mathrm{PM}_{2.5}$ averaged at $2.1 \%$, Table 4). High concentrations of $\mathrm{K}, \mathrm{S}, \mathrm{Cl}$, but also $\mathrm{Ca}, \mathrm{Co}, \mathrm{Sr}$ and $\mathrm{Cd}$ were recorded on days when the air masses came from the SW and SSW, which are the directions of scattered sources of $\mathrm{PM}_{2.5}$ - small local boiler houses and individual domestic cookers and stoves. It is worth mentioning here that the contribution of coal and biomass combustion to the concentrations of $\mathrm{PM}_{2.5}$ in Warsaw, seems to be relatively small in winter, considering the results of earlier research carried out in the south of Poland (Juda-Rezler et al. 2011; Sówka et al. 2012; Rogula-Kozłowska et al. 2012, 2013a, 2014). To some extent, this could be blamed on the limited quantity of data used to perform PCA and MLRA and the ensuing error of estimation. Although such an error could not have been completely avoided, looking at the list of concentrations in Table 2, we can clearly see that the obtained result is sensible. The concentrations of $\mathrm{K}, \mathrm{S}$ and $\mathrm{Cl}$ in Warsaw, were outstandingly lower than in south Poland. However, these low values did not result from a low concentration of $\mathrm{PM}_{2.5}$, which can be proven by high (higher than in the south part of the country) concentrations of other elements. It seems that the number of buildings provided with heat by central heating systems is a few times greater in Warsaw, than in the south, where a lot more houses have independent heating. Moreover, in Warsaw - the most developed and one of the richest places in Poland - residential houses and buildings with independent heating systems more often use natural gas as heating fuel. Biomass is used only in houses with fireplaces, small local boiler houses and large coal-fired CHP plants as an additive. Coal, on the other hand, is hardly used in households as a heat source, whereas in the south of Poland, it is commonly burned in obsolete, low-efficiency stoves from early autumn until late spring, often with household waste, including plastics and other materials. Therefore, it can be claimed that in winter, Warsaw demonstrates an actual contribution of coal and biomass power generation to the concentrations of $\mathrm{PM}_{2.5}$. The contribution is largely determined by emissions from CHP plants, power plants and local boiler houses. Home stoves in Warsaw, are most likely mainly accountable for the emissions of PM from biomass combustion.

The concentrations of certain elements, particularly V, Co, $\mathrm{Ni}$, Sr and $\mathrm{Cd}$, were evidently higher (up to a few times) than their respective concentrations recorded in other parts of the country. This is puzzling in the context of low-much lower than in other regions - concentrations of $\mathrm{PM}_{2.5}$ in Warsaw, in winter. Exceptionally high concentrations of V, Co, Ni, Sr and $\mathrm{Cd}$ were observed when air masses were flowing from the ESE and SW directions, where residential buildings with individual stoves and oil-and-gas-fired boilers prevail. An analysis of elemental profiles of the sources of $\mathrm{PM}_{2.5}$ (Table 5) indicates that the source of these elements must be an oil-fired power plant, and high correlation values of $\mathrm{V}, \mathrm{Ni}, \mathrm{Co}$ and $\mathrm{Cr}$ with PC6 and PC7 confirm this (Table 4). The contribution of emissions from oil-fired power plants to the concentrations of $\mathrm{PM}_{2.5}$ in Warsaw, reached $9.9 \%$; its diurnal values ranged from 8.1 to $12.3 \%$ and were negatively correlated with the air temperature $\left(R^{2}=-0.27\right)$. In other parts of Poland, such a clear influence of heating oil combustion on PM concentrations had not been observed before. It is obvious that the reason for this is the small number of modern oil-and-gas boiler houses in other parts of the country, especially in the south, where most of the data published on the chemical composition of $\mathrm{PM}_{2.5}$ originates. In European cities and in the USA, the situation is like in Warsaw, as partially suggested by the concentrations of Ni and V there (Table 1).

In the SW, as well as the WSW, there is a dense network of streets and roads with a substantial traffic load. The minimum distance of a busy road from a measurement site is $500 \mathrm{~m}$ in the SW and $1000 \mathrm{~m}$ in the WSW. On days with the wind coming from the SW and WSW, high concentrations of S, V, $\mathrm{Cr}, \mathrm{Mn}, \mathrm{Fe}, \mathrm{Zn}$ and $\mathrm{Pb}$ were observed. Some of these elements were strongly correlated with PC8 (Table 4). An analysis of the elemental profiles of $\mathrm{PM}_{2.5}$ from Table 5 allowed for the assumption that PC8 must have implied another source of $\mathrm{PM}_{2.5}$, i.e. motor vehicles. The mean contribution of emissions from the engines of motor vehicles to the concentrations of $\mathrm{PM}_{2.5}$ at the time of the observations was $15.7 \%$, which had changed from 11.4 to $22.3 \%$ on individual days. This value was positively correlated with the air temperature $\left(R^{2}=0.19\right)$. Of course, at higher temperatures, when the contribution of domestic stoves and other power-generation sources (boiler houses and CHP plants) to the concentrations of $\mathrm{PM}_{2.5}$ decreased, the role of traffic emissions in the shaping of air pollution by fine PM increased. The values of diurnal contribution of emissions from motor vehicles to the concentrations of $\mathrm{PM}_{2.5}$ were also positively correlated with precipitation $\left(R^{2}=0.30\right.$; Fig. 2$)$, which means that at the time of rain or snowfall, the contribution of this source to the concentrations of $\mathrm{PM}_{2.5}$ increased. Most probably, very small (nanoand ultrafine) particles emitted with car exhausts were not 
Table 5 Compounds in $\mathrm{PM}_{2.5}$ from various sources and in ambient $\mathrm{PM}_{2.5}$ in winter in Warsaw

\begin{tabular}{|c|c|c|c|c|c|c|c|c|}
\hline & $<0,1 \%$ & & $0,1-1 \%$ & & $1-10 \%$ & & $>10 \%$ & \\
\hline & Source & ${ }^{*} \mathrm{PM}_{2.5}$ & Source & $\mathrm{PM}_{2.5}$ & Source & $\mathrm{PM}_{2.5}$ & Source & $\mathrm{PM}_{2.5}$ \\
\hline $\begin{array}{l}\text { Motor } \\
\text { vehicles }\end{array}$ & ${ }^{\mathrm{a}} \mathrm{Cr}, N i, \mathrm{Y}, S r, \mathrm{Ba}$ & \multirow{4}{*}{$\begin{array}{l}\mathrm{Sc}, \mathrm{Ti}, \\
\mathrm{Cr}, \mathrm{Mn}, \\
\mathrm{Co}, \mathrm{Ni}, \\
\mathrm{Sr},\end{array}$} & $\mathrm{Si}, C l, \mathrm{Al}, \mathrm{P}, \mathrm{Ca}, M n, \mathrm{Fe}, Z n, B r, P b$ & \multirow{4}{*}{$\begin{array}{l}\mathrm{Mg}, \mathrm{Cl}, \\
\mathrm{K}, \mathrm{V}, \\
\mathrm{Cu}, \mathrm{Zn}, \\
\mathrm{As}, \mathrm{Se}, \\
\mathrm{Br}, \mathrm{Cd}, \\
\mathrm{Pb}\end{array}$} & $\begin{array}{l}\mathrm{SO}_{4}{ }^{=}, \mathrm{NH}_{4}{ }^{+} \\
\mathrm{S}, \mathrm{Cl}^{-}, \mathrm{NO}_{3}\end{array}$ & \multirow{4}{*}{$\begin{array}{l}\mathrm{Na}, \\
\mathrm{Al}, \mathrm{Si}, \\
\mathrm{S}, \mathrm{Ca}, \\
\mathrm{Fe},\end{array}$} & OC,EC & \multirow{5}{*}{-} \\
\hline $\begin{array}{l}\text { Biomass } \\
\text { combustion }\end{array}$ & $\begin{array}{l}\mathrm{Ca}, \mathrm{Fe}, \mathrm{Mn}, \mathrm{Zn} \\
\mathrm{Br}, \mathrm{Rb}, \mathrm{Pb}\end{array}$ & & $\mathrm{NO}_{3}^{-}, \mathrm{SO}_{4}{ }^{=}, \mathrm{NH}_{4}^{+} \mathrm{Na}^{+}, \mathrm{S}$ & & $\mathrm{Cl}^{-}, \mathrm{K}^{+}, C l, K$ & & OC,EC & \\
\hline $\begin{array}{l}\text { Coal-fired } \\
\text { boiler }\end{array}$ & $\begin{array}{l}\mathrm{Cl}, \mathrm{Cr}, \mathrm{Mn}, \mathrm{Ga}, \mathrm{As} \\
\mathrm{Se}, \mathrm{Br}, \mathrm{Rb}, \mathrm{Zr}\end{array}$ & & $\begin{array}{l}\mathrm{NH}_{4}^{+}, \mathrm{P}, K, \mathrm{Ti}, \mathrm{V} \\
\mathrm{Ni}, \mathrm{Zn}, \mathrm{Sr}, \mathrm{Ba}, \mathrm{Pb}\end{array}$ & & $\begin{array}{l}\mathrm{SO}_{4}{ }_{4}, \mathrm{OC}, \mathrm{EC} \\
\mathrm{Al}, \mathrm{S}, \mathrm{Ca}, \mathrm{Fe}\end{array}$ & & $\mathrm{Si}$ & \\
\hline $\begin{array}{l}\text { Oil-fired } \\
\text { power plant }\end{array}$ & $\begin{array}{l}\mathrm{V}, \mathrm{Ni}, \mathrm{Se}, \mathrm{As}, \mathrm{Br} \\
\mathrm{Ba}\end{array}$ & & $\mathrm{Al}, \mathrm{Si}, \mathrm{P}, K, Z n$ & & $\begin{array}{l}\mathrm{NH}_{4}{ }^{+}, \mathrm{OC}, \mathrm{EC} \\
\mathrm{Na}, \mathrm{Ca}, \mathrm{Pb}\end{array}$ & & $\mathrm{S}, \mathrm{SO}_{4}=$ & \\
\hline $\begin{array}{l}\text { Antimony } \\
\text { roaster }\end{array}$ & $\mathbf{V}, \mathrm{Cl}, \mathrm{Ni}, \mathrm{Mn}$ & & $\mathrm{SO}_{4}{ }^{=}, \mathrm{Sb}, P b$ & & $S$ & & - & \\
\hline
\end{tabular}

Reference: (Chow 1995)

*The arithmetic mean of the diurnal element contributions to the $\mathrm{PM}_{2.5}$ mass was the criterion for the elements to be included into a proper group $(<0.1 \%, 0.1-1 \%, 1-10 \%)$

${ }^{\text {a }}$ Symbols in red denote the elements occurring in Warsaw $\mathrm{PM}_{2.5}$ in amounts equal to amounts in the emission profiles from Chow 1995, blue symbols denote the elements occurring in amounts greater than amounts assigned to the sources by Chow, and green symbols denote the elements whose amount in Warsaw $\mathrm{PM}_{2.5}$ is too low to classify them into the proper Chow group and they belong to the preceding one

washed away by short-term precipitation. Larger particles, on the other hand, coming from other sources and/or particles that are suspended in the air long enough to form clusters and/or agglomerates when transported and transformed (Hinds 1999; Seinfeld and Pandis 2012) are easily and quickly washed away from the atmosphere (Seinfeld and Pandis 2012). Thus, it can be assumed that when the share of particles emitted from other sources in the concentrations of $\mathrm{PM}_{2.5}$ decreases, the share of motor vehicle engine emissions indirectly increases.

The last identified source of $\mathrm{PM}_{2.5}$ in Warsaw, was soil and road dust (PC9 and PC10, whose mean contribution to the concentrations of $\mathrm{PM}_{2.5}$ at the time of observations was $8 \%$ ). This source was identified mainly owing to the high correlations of crustal elements, $\mathrm{Ti}, \mathrm{Al}$ and $\mathrm{Si}$ (Table 1) with the principal components (Table 4). Since Ni, Mn and Cd, the source of which was friction of vehicle components (car bodies, brake pads and discs, exhaust pipes etc.) (Thorpe and Harrison 2008), which also correlated with PC9 and PC10. It was determined that they did not come only from soil matter, but from a combination of soil matter and road dust (mechanical processes-non-exhaust emissions). The diurnal contributions of this source to the concentrations of $\mathrm{PM}_{2.5}$ ranged from 5.0 to $10.3 \%$ and were positively correlated with the wind speed $\left(R^{2}=0.17\right)$.

The exclusive contribution of soil matter (SM) to $\mathrm{PM}_{2.5}$ (without road dust) can be easily estimated. The elements that were viewed as of crustal/soil origin in Warsaw, (i.e. whose
Fig. 3 Diurnal contributions (\%) of $\mathrm{PM}_{2.5}$-bound soil matter (SM) to $\mathrm{PM}_{2.5}$ mass

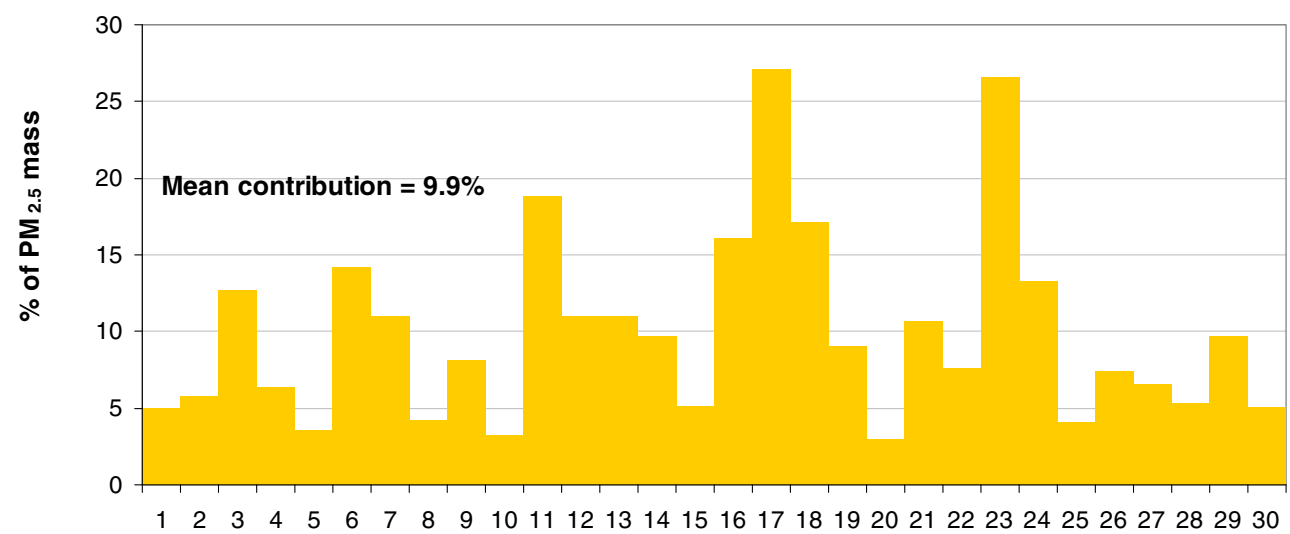


$\mathrm{EF}_{x}$ was up to 5: $\mathrm{Mg}, \mathrm{Al}, \mathrm{Si}$, $\mathrm{Ti}$ and $\mathrm{Fe}$ - Table 2) occurred in soil mainly in the form of oxides and carbonates. Their most common compounds are $\mathrm{SiO}_{2}, \mathrm{Al}_{2} \mathrm{O}_{3}, \mathrm{Fe}_{2} \mathrm{O}_{3}$ and $\mathrm{TiO}_{2}$.

Therefore, the mass concentration of soil matter [SM] was determined using the following formula:

$$
[\mathrm{SM}]=\left[\mathrm{SiO}_{2}\right]+\left[\mathrm{Al}_{2} \mathrm{O}_{3}\right]+\left[\mathrm{Fe}_{2} \mathrm{O}_{3}\right]+\left[\mathrm{TiO}_{2}\right]+\left[\mathrm{CO}_{3}{ }^{2-}\right]
$$

where $\left[\mathrm{SiO}_{2}\right],\left[\mathrm{Al}_{2} \mathrm{O}_{3}\right],\left[\mathrm{Fe}_{2} \mathrm{O}_{3}\right]$, and $\left[\mathrm{TiO}_{2}\right]$ were calculated stoichiometrically from the analytically determined [Si], [Al], $[\mathrm{Fe}]$ and $[\mathrm{Ti}] ;\left[\mathrm{CO}_{3}{ }^{2-}\right]=1.5\left[\mathrm{Ca}^{2+}\right]_{\mathrm{A}}+2.5\left[\mathrm{Mg}^{2+}\right]_{\mathrm{A}}$ (Marcazzan et al. 2001). In this paper, the quantities of $\mathrm{Ca}$ and $\mathrm{Mg}$ in water-soluble compounds $\left(\mathrm{Ca}^{2+}\right.$ and $\left.\mathrm{Mg}^{2+}\right)$ were not determined, but they were calculated using the values of analytically determined mass concentrations of $\mathrm{Ca}$ and $\mathrm{Mg}([\mathrm{Ca}]$ and $[\mathrm{Mg}]$ ), as well as the conclusions of the research described in Rogula-Kozłowska et al. (2013a) which demonstrate that more than $50 \%$ of the mass of $\mathrm{PM}_{2.5}$-bound $\mathrm{Ca}$ and $\mathrm{Mg}$ in an urban area in Poland occurs in water-soluble compounds. Therefore, it was assumed that $\left[\mathrm{Ca}^{2+}\right]=0.5[\mathrm{Ca}]$ and $\left[\mathrm{Mg}^{2+}\right]=$ $0.5[\mathrm{Mg}]$.

The average concentration of soil matter in air at the time of the observations was $1.14 \mu \mathrm{g} / \mathrm{m}^{3}$. The mean contribution of $\mathrm{SM}$ to the mass of $\mathrm{PM}_{2.5}$ was estimated at nearly $10 \%$ (Fig. 3). Therefore, the estimated contribution corresponds well to the contribution of soil and road dust to $\mathrm{PM}_{2.5}$, calculated using MLRA. Even if the contribution of SM to $\mathrm{PM}_{2.5}$, calculated in a simplified way, is largely overestimated, it is still evident that soil matter makes the principal component of PM in Warsaw, from the source identified herein as 'soil and road dust' or - in other words - a component of PM from soil and road surface erosion processes and re-suspension of dust.

\section{Conclusions}

In winter, the concentrations of $\mathrm{PM}_{2.5}$ in Warsaw, are low, in comparison to the values recorded in other parts of Poland and in most urban areas worldwide. Nevertheless, concentrations of some $\mathrm{PM}_{2.5}$-elements, mainly toxic ( $\mathrm{Se}, \mathrm{Ar}, \mathrm{Co}, \mathrm{V}, \mathrm{Cd}, \mathrm{Ni}$ ), may reach high values. This suggests that despite low concentrations of $\mathrm{PM}_{2.5}$ in the air, there exists substantial exposure of the residents to the negative impact of the toxic components of $\mathrm{PM}$. This is highly probable, because the measurements were taken in an urban background area where generally observed levels should be lower than in areas located in the vicinity of the major sources of $\mathrm{PM}_{2.5}$.

In Warsaw, $\mathrm{PM}_{2.5}$ and $\mathrm{PM}_{2.5}$-elements come from four sources of emissions. Coal and biomass combustion accounts for nearly $18.4 \%$ of fine PM in the air. The contributions of oil-fired power plants, motor vehicles and soil/road dust to the concentrations of $\mathrm{PM}_{2.5}$ amount to $9.9,15.7$ and $8.0 \%$, respectively. The total share of identified sources of emissions in the concentrations of $\mathrm{PM}_{2.5}$ is a little over $50 \%$, which means that nearly $50 \%$ of $\mathrm{PM}_{2.5}$ in the analysed area may be socalled background concentration. Results of earlier studies of the concentrations of $\mathrm{PM}_{2.5}$ in an area where the countryspecific background concentration was measured for $\mathrm{PM}_{2.5}$ (Diabla Góra) support this conclusion (Rogula-Kozłowska et al. 2014).

It can also be expected that some PM from unidentified sources is secondary aerosol, originating from the transformations of organic and inorganic gaseous precursors of PM. In order to validate this conclusion, it is necessary to determine the content of water-soluble ions and carbonaceous matter in $\mathrm{PM}_{2.5}$.

The results obtained in this paper come from the first series of observations conducted in the area of the Warsaw conurbation; however, the series was short and covered winter only. Therefore, they should be interpreted with a degree of caution and the conclusions must not be applied to areas of central Poland outside the Warsaw conurbation. Yet the research evidently demonstrates that the concentrations of both $\mathrm{PM}_{2.5}$ and $\mathrm{PM}_{2.5}$-bound elements follow similar patterns in the central part of the country and in other urban areas of Europe, but not in the south of Poland. Due to the prevailing western and south-western winds, it seems that the area of central Poland may be substantially affected by pollution carried from the south of the country.

Acknowledgments The work was carried out within the project No. 2012/07/D/ST10/02895 (ID 202319) financed by the National Science Centre Poland (NCN).

Open Access This article is distributed under the terms of the Creative Commons Attribution 4.0 International License (http:// creativecommons.org/licenses/by/4.0/), which permits unrestricted use, distribution, and reproduction in any medium, provided you give appropriate credit to the original author(s) and the source, provide a link to the Creative Commons license, and indicate if changes were made.

\section{References}

Aldabe J, Elustondo D, Santamaría C, Lasheras E, Pandolfi M, Alastuey A, Querol X, Santamaría JM (2011) Chemical characterization and source apportionment of PM2.5 and PM10 at rural, urban and traffic sites in Navarra (north of Spain). Atmos Res 102:191-205

Alolayan M, Brown KW, Evans JS, Bouhamra WS, Koutrakis P (2013) Source apportionment of fine particles in Kuwait City. Sci Total Environ 448:4-25

Badyda AJ, Dąbrowiecki P, Czechowski PO, Majewski G, Doboszyńska A (2015) Traffic-related air pollution and respiratory tract efficiency. Adv Exp Med Biol 834:31-38

Baxter LK, Duvall RM, Sacks J (2013) Examining the effects of air pollution composition on within region differences in $\mathrm{PM}_{2.5}$ mortality risk estimates. J Expo Sci Environ Epidemiol 23:457-465

Belis CA, Karagulian F, Larsen BR, Hopke PK (2013) Critical review and meta-analysis of ambient particulate matter source apportionment using receptor models in Europe. Atmos Environ 69:94-108 
Bozlaker A, Prospero JM, Fraser MP, Chellam S (2013) Quantifying the contribution of long-range Saharan dust transport on particulate matter concentrations in Houston, Texas, using detailed elemental analysis. Environ Sci Technol 47(18):10179-10187

Calvo A, Alves C, Castro A, Pont V, Vicente A, Fraile R (2013) Research on aerosol sources and chemical composition: past, current and emerging issues. Atmos Res 120:1-28

Campos-Ramos AA, Aragon-Pina A, Alastuey A, Galindo-Estrada I, Querol X (2011) Levels composition and source apportionment of rural background PM10 in western Mexico (state of Colima). Atmos Pollut Res 2:409-417

Cheng H, Gong W, Wang Z, Zhang F, Wang X, Lv X, Liu J, Fu X, Zhang $G$ (2014) Ionic composition of submicron particles (PM1) during the long-lasting haze period in January 2013 in Wuhan, central China. J Environ Sci 26:810-817

Chiou PW, Tang CJ, Lin H, Chu W, Ho TC (2009) Atmospheric aerosol over a southeastern region of Texas: chemical composition and possible sources. Environ Model Assess 14:333-350

Chow JC (1995) Measurement methods to determine compliance with ambient air quality standards for suspended particles. J Air Waste Manage Assoc 45:320-382

Cohen DD, Crawford J, Stelcer E, Bac VT (2010) Characterisation and source apportionment of fine particulate sources at Hanoi from 2001 to 2008. Atmos Environ 44:320-328

Costa DL, Dreher KL (1997) Bioavailable transition metals in particulate matter mediate cardiopulmonary injury in healthy and compromised animal models. Environ Health Perspect 105:1053-1060

Cuccia E, Massabò D, Ariola V, Bove MC, Fermo P, Piazzalunga A, Prati P (2013) Size-resolved comprehensive characterization of airborne particulate matter. Atmos Environ 67:14-26

Czarnecka M, Nidzgorska-Lencewicz J (2014) Intensity of urban heat island and air quality in Gdańsk during 2010 heat wave. Pol J Environ Stud 23(2):329-340

Daher N, Ruprecht A, Invernizzi G, De Marco C, Miller-Schulze J, Bae Heo J, Shafer MM, Shelton BR, Schauer JJ, Sioutas C (2012) Characterization, sources and redox activity of fine and coarse particulate matter in Milan, Italy. Atmos Environ 49:130-141

Daher N, Saliba NA, Shihadeh AL, Jaafar M, Baalbaki R, Shafer MM, Schauer JJ, Sioutas C (2014) Oxidative potential and chemical speciation of size-resolved particulate matter (PM) at near-freeway and urban background sites in the greater Beirut area. Sci Total Environ 470:417-426

Davis JA, Meng Q, Sacks JD, Dutton SJ, Wilson WE, Pinto JP (2011) Regional variations in particulate matter composition and the ability of monitoring data to represent population exposures. Sci Total Environ 409:5129-5135

Dieme D, Cabral-Ndior M, Garçon G, Verdin A, Billet S, Cazier F, Courcot D, Diouff A, Shirali P (2012) Relationship between physicochemical characterization and toxicity of fine particulate matter $\left(\mathrm{PM}_{2.5}\right)$ collected in Dakar city (Senegal). Environ Res 113:1-13

Duvall RM, Majestic BJ, Shafer MM, Chuang PY, Simoneit BRT, Schauer JJ (2008) The water-soluble fraction of carbon, sulfur, and crustal elements in Asian aerosols and Asian soils. Atmos Environ 42:5872-5884

EC (2004) Council Directive 2004/107/EC relating to arsenic, cadmium, mercury, nickel and polycyclic aromatic hydrocarbons in ambient air

Englert N (2004) Fine particles and human health — a review of epidemiological studies. Toxicol Lett 149:235-242

Fernandez AJ, Ternero M, Barragan FJ, Jimenez JC (2001) Size distribution of metals in urban aerosols in Seville (Spain). Atmos Environ 35:2595-2601

Fernández-Camacho R, Rodríguez S, de la Rosa J, Sánchez de la Campa AM, Alastuey A, Querol X, González-Castanedo Y, GarciaOrellana I, Nava S (2012) Ultrafine particle and fine trace metal
(As, $\mathrm{Cd}, \mathrm{Cu}, \mathrm{Pb}$ and $\mathrm{Zn}$ ) pollution episodes induced by industrial emissions in Huelva, SW Spain. Atmos Environ 61:507-517

Friend AJ, Ayoko GA, Guo H (2011) Multi-criteria ranking and receptor modelling of airborne fine particles at three sites in the Pearl River Delta region of China. Sci Total Environ 409:719-737

Goyer RA (1986) Toxic effects of metals. In: Klaassen CD, Amdur MO, Doull J (eds) Casarett and Doull's toxicology; the basic science of poisons, 3rd edn. Macmillan, New York, pp 582-635

Halek F, Kianpour-Rad M, Darbani RM, Kavousirahim A (2010) Concentrations and source assessment of some atmospheric trace elements in northwestern region of Tehran, Iran. Bull Environ Contam Toxicol 84:185-190

Hinds WC (1999) Aerosol technology. Properties, behavior, and measurement of airborne particles, Second Editionth edn. John Wiley \& Sons, Inc, New York

Jorquera H, Barraza F (2012) Source apportionment of ambient $\mathrm{PM}_{2.5}$ in Santiago, Chile: 1999 and 2004 results. Sci Total Environ 435-436: 418-429

Jorquera H, Barraza F (2013) Source apportionment of $\mathrm{PM}_{10}$ and $\mathrm{PM}_{2.5}$ in a desert region in northern Chile. Sci Total Environ 444:327-335

Juda-Rezler K, Reizer M, Oudinet JP (2011) Determination and analysis of $\mathrm{PM}_{10}$ source apportionment during episodes of air pollution in central eastern European urban areas: The case of wintertime 2006. Atmos Environ 45:6557-6566

Juda-Rezler K, Kowalczyk D (2013) Size distribution and trace elements contents of coal fly ash from pulverized boilers. Pol J Environ Stud 22(1):25-40

Kennedy IM (2007) The health effects of combustion-generated aerosols. Proc Combust Inst 31:2757-2770

Krzemińska-Flowers M, Bem H, Górecka H (2006) Trace metals concentration in size-fractioned urban air particulate matter in Łódź, Poland. I. Seasonal and site fluctuations. Pol J Environ Stud 15(5): 759-767

Kumar P, Pirjola L, Ketzel M, Harrison RM (2013) Nanoparticle emissions from 11 non-vehicle exhaust sources - a review. Atmos Environ 67:252-277

Lemos AT, Coronas MV, Rocha JAV, Vargas VMF (2012) Mutagenicity of particulate matter fractions in areas under the impact of urban and industrial activities. Chemosphere 89:1126-1134

Lestari P, Mauliadi YD (2009) Source apportionment of particulate matter at urban mixed site in Indonesia using PMF. Atmos Environ 43: $1760-1770$

Lettino A, Caggiano R, Fiore S, Macchiato M, Sabia S, Trippetta S (2012) Eyjafjallajökull volcanic ash in southern Italy. Atmos Environ 48:97-103

Lewandowska AU, Falkowska LM (2013) High concentration episodes of PM10 in the air over the urbanized coastal zone of the Baltic Sea (Gdynia-Poland). Atmos Res 120-121:55-67

Lippmann M (2008) Environmental toxicants: human exposures and their health effects. Third Edition. John Wiley \& Sons

Majewski G, Kleniewska M, Brandyk A (2011) Seasonal variation of particulate matter mass concentration and content of metals. Pol J Environ Stud 20(2):417-427

Majewski G, Kleniewska M, Przewoźniczuk W (2014) The effect of urban conurbation on the modification of human thermal perception, as illustrated by the example of Warsaw (Poland). Theor Appl Climatol 116(1-2):147-154

Mansha M, Ghauri B, Rahman S, Amman A (2012) Characterization and source apportionment of ambient air particulate matter $\left(\mathrm{PM}_{2.5}\right)$ in Karachi. Sci Total Environ 425:176-183

Marcazzan GM, Vaccaro S, Valli G, Vecchi R (2001) Characterisation of PM10 and PM2.5 particulate matter in the ambient air of Milan (Italy). Atmos Environ 35:4639-4650

Murillo JH, Ramos AC, García FÁ, Jiménez SB, Cárdenas B, Mizohata A (2012) Chemical composition of $\mathrm{PM}_{2.5}$ particles in Salamanca, 
Guanajuato Mexico: source apportionment with receptor models. Atmos Res 107:31-41

Murillo JH, Roman SR, Marin JFR, Ramos AC, Jimenez SB, Gonzalez BC, Baumgardner DG (2013) Chemical characterization and source apportionment of PM10 and PM2.5 in the metropolitan area of Costa Rica, Central America. Atmos Pollut Res 4:181-190

$\mathrm{Na}$ K, Cocker DR III (2009) Characterization and source identification of trace elements in PM2.5 from Mira Loma, southern California. Atmos Res 93:793-800

Osornio-Vargas AR, Serrano J, Rojas-Bracho L, Miranda J, GarcíaCuellar C, Reyna MA, Flores G, Zuk M, Quintero M, Vázquez I et al (2011) In vitro biological effects of airborne $\mathrm{PM}_{2.5}$ and $\mathrm{PM}_{10}$ from semi-desert city on the Mexico-US border. Chemosphere 83: 618-626

Pancras JP, Landis MS, Norris GA, Vedantham R, Dvonch JT (2013) Source apportionment of ambient fine particulate matter in Dearborn, Michigan, using hourly resolved PM chemical composition data. Sci Total Environ 448:2-13

Pastuszka JS, Rogula-Kozłowska W, Zajusz-Zubek E (2010) Characterization of PM10 and PM2.5 and associated heavy metals at the crossroads and urban background site in Zabrze, Upper Silesia, Poland, during the smog episodes. Environ Monit Assess 168:613-627

Pope CA, Dockery DW (2006) Health effects of fine particulate air pollution: lines that connect. J Air Waste Manag Assoc 56:709-742

Putaud JP, Van Dingenen R, Alastuey A, Bauer H, Birmili W, Cyrys J, Flentje H, Fuzzi S, Gehrig R, Hansson HC et al (2010) A European aerosol phenomenology-3: physical and chemical characteristics of particulate matter from 60 rural, urban, and kerbside sites across Europe. Atmos Environ 44:1308-1320

Rogula-Kozłowska W, Błaszczak B, Szopa S, Klejnowski K, Sówka I, Zwoździak A, Jabłońska M, Mathews B (2013a) PM2.5 in the central part of Upper Silesia, Poland: concentrations, elemental composition, and mobility of components. Environ Monit Assess 185: 581-601

Rogula-Kozłowska W, Klejnowski K, Rogula-Kopiec P, Ośródka L, Krajny E, Błaszczak B, Mathews B (2014) Spatial and seasonal variability of the mass concentration and chemical composition of $\mathrm{PM}_{2.5}$ in Poland. Air Qual Atmos Health 7:41-58

Rogula-Kozłowska W, Klejnowski K, Rogula-Kopiec P, Mathews B, Szopa SA (2012) Study on the seasonal mass closure of ambient fine and coarse dusts in Zabrze, Poland. Bull Environ Contam Toxicol 88:722-729

Rogula-Kozłowska W, Rogula-Kupiec P, Mathews B, Klejnowski K (2013b) Effects of road traffic on the ambient concentrations of three PM fractions and their main components in a large Upper Silesian city. Ann Warsaw Univ Life Sci - SGGW Land Reclam 45:243-253

Sanderson P, Delgado-Saborit JM, Harrison RM (2014) A review of chemical and physical characterisation of atmospheric metallic nanoparticles. Atmos Environ 94:353-365

Schleicher NJ, Norra S, Chai F, Chen Y, Wang S, Cen K, Yang Y, Stüben D (2011) Temporal variability of trace metal mobility of urban particulate matter from Beijing - a contribution to health impact assessments of aerosols. Atmos Environ 45:7248-7265

Seinfeld JH, Pandis SN (2012) Atmospheric chemistry and physics: from air pollution to climate change. John Wiley \& Sons
Singh DP, Gadi R, Mandal TK (2011) Characterization of particulatebound polycyclic aromatic hydrocarbons and trace metals composition of urban air in Delhi, India. Atmos Environ 45:7653-7663

Sówka I, Zwoździak A, Trzepla-Nabaglo K, Skrętowicz M, Zwoździak J (2012) PM2.5 elemental composition and source apportionment in residential area of Wrocław, Poland. Environ Prot Eng 38:73-79

Swaine DJ (2000) Why trace elements are important. Fuel Process Technol 65-66:21-33

Szoboszlai Z, Kertész Z, Szikszai Z, Angyal A, Furu E, Török Z, Daróczi L, Kiss ÁZ (2012) Identification and chemical characterization of particulate matter from wave soldering processes at a printed circuit board manufacturing company. J Hazard Mater 203:308-316

Thorpe A, Harrison RM (2008) Sources and properties of non-exhaust particulate matter from road traffic: a review. Sci Total Environ 400: 270-282

Thurston GD, Spengler JD (1985) A quantitative assessment of source contribution to inhalable particulate matter pollution in metropolitan Boston. Atmos Environ 19:9-25

Viana M, Kuhlbusch TAJ, Querol X, Alastuey A, Harrison RM, Hopke PK, Winiwarter W, Vallius M, Szidat S, Prevot ASH et al (2008a) Source apportionment of particulate matter in Europe: a review of methods and results. J Aerosol Sci 39:827-849

Viana M, Querol X, Alastuey A, Ballester F, Llop S, Esplugues A, Fernández-Patier R, Garcia dos Santos S, Herce MD (2008b) Characterising exposure to $\mathrm{PM}$ aerosols for an epidemiological study. Atmos Environ 42:1552-1568

von Schneidemesser E, Stone EA, Quraishi TA, Shafer MM, Schauer JJ (2010) Toxic metals in the atmosphere in Lahore, Pakistan. Sci Total Environ 408:1640-1648

Wang J, Hu Z, Chen Y, Chen Z, Xu S (2013) Contamination characteristics and possible sources of PM10 and PM2.5 in different functional areas of Shanghai, China. Atmos Environ 68: 221-229

Wedepohl KH (1995) The composition of the continental crust. Geochim Cosmochim Acta 59(7):1217-1232

WHO (2000) Air quality guidelines for Europe, 2nd edn. Regional Office for Europe 2000, Copenhagen

Wiseman CL, Zereini F (2009) Airborne particulate matter, platinum group elements and human health: a review of recent evidence. Sci Total Environ 407:2493-2500

Xu L, Chen X, Chen J, Zhang F, He C, Zhao J, Yin L (2012) Seasonal variations and chemical compositions of $\mathrm{PM}_{2.5}$ aerosol in the urban area of Fuzhou, China. Atmos Res 104:264-272

Yang L, Zhou X, Wang Z, Zhou Y, Cheng S, Xu P, Gao X, Nie W, Wang X, Wang W (2012) Airborne fine particulate pollution in Jinan, China: concentrations, chemical compositions and influence on visibility impairment. Atmos Environ 55:506-514

Zhang W, Lei T, Lin ZQ, Zhang HS, Yang DF, Xi ZG, Chen JH, Wang W (2011) Pulmonary toxicity study in rats with PM10 and PM2.5: differential responses related to scale and composition. Atmos Environ 45:1034-1041

Zwoździak A, Sówka I, Krupińska B, Zwoździak J, Nych A (2013) Infiltration or indoor sources as determinants of the elemental composition of particulate matter inside a school in Wrocław, Poland? Build Environ 66:173-180 